and substandard performance, and this makes it increasingly difficult for organisations to remain competitive in the changing global marketplace. Employee creativity needs a fuller expression at work but such expression is difficult when work itself is immensely repetitive and not meaningful (Neck \& Milliman 1994:10). Denton (2007) suggests that other modern developments such as an increasingly need-driven and anxious society together with the separate positions of employer and employee in the pursuit of the financial bottom line further informs the search for meaning.

Given the highly competitive nature of business, human capital often gives the competitive edge to an organisation and valuable employees must be retained. The current motivational paradigm needs to incorporate the spiritual dimension of employees, which is the missing link in understanding the problems of underperformance and ineffectiveness. The argument is advanced that spirituality, an increasingly embraced phenomenon, provides meaning and purpose in the lives of individuals and that it could be positively applied to workplace spirituality (Kinjerski \& Skrypnek 2004). Workplace spirituality, viewed as sensitive and controversial, has the potential to develop leadership as it allows employees and leaders to act from personal truth, integrity, values and ethical practice (Neck \& Milliman 1994; Rego \& Pina e Cunha 2008). Spiritual leadership is seen to have the potential to tap into the fundamental needs of both leader and follower for spiritual survival, the antidote to meaninglessness, so they become more organisationally committed and productive.

This article focuses on spiritual leadership as necessary for the transformation and continued success of an organisation. Spiritual leadership involves motivating and inspiring workers through a transcendent vision and culture based on altruist values to produce a more motivated, committed and productive workforce.

\section{What is workplace spirituality?}

As society has advanced in terms of leisure time, technology and the communication of ideas, people increasingly desire to experience spirituality not only in their personal lives but also in their work, where they spend a large amount of time (Neck \& Milliman 1994). According to Ashmos and Duchon (2000:3), the spiritual dimension of human beings, namely that dimension concerned with finding meaning and purpose and living in relation to others, was not welcomed in the bureaucratic and scientific management models of the workplace (which has been the dominant organisational paradigm since the beginning of the Industrial Revolution). However, the notion that spirituality should not be brought to work is not pragmatic, as employees are holistic beings and may link their personal self-image with who they are in the world of work.

In the work environment, employees faced with conflicting value sets in their personal and professional lives are challenged by the decision to conform, leave or alter the organisation (Chatman 1991). More workers are choosing the last option, seeking self-actualisation through their work lives by acting as change agents. They are not willing to compromise their personal values for the sake of their professional careers, nor are they willing to do the reverse. In the process, they are striving to 'express and develop their complete self at work' by bringing their personal values, used here as synonymous with spiritual beliefs, into the workplace (Mitroff \& Denton 1999; Lund Dean \& Safranski 2008:359). These individuals derive a sense of selfactualisation (Maslow 1954) through their actions, a sense of sacredness and purpose through their work that allows them to feel more genuine and authentic in resolving conflicted value systems and shaping new ones (Ray \& Anderson 2000). For these and other reasons, people search for ways to 'leave a legacy', to achieve satisfaction in knowing that their lives made the world a better place (Covey 1995). For some, this involves a religious connotation, whilst for others it does not. These values drive them to experience a higher sense of service in making a difference by contributing to society as a whole (Delbecq 1999). As a result, the nature of their work changes from a career in which they earn a living to a vocation in which they express themselves and promote positive social change (Fry 2003). It may be assumed that employees not only become personally fulfilled but the organisation reaps the benefits of high morale, a decrease in absenteeism and, ultimately, profits.

At the same time, the idea of 'work as vocation' may be idealistic for many sectors and societies. In South Africa some occupations that were traditionally viewed as noble professions or vocations such as teaching, nursing and law enforcement have lost their glory (Penceliah 2009:211). Owing to the high unemployment rate, many see work as a way to survive. It is also important to mention that some people see a lack of safety in expressing spirituality in the workplace (Lipps-Wiersma \& Mills 2002:191). This is because spirituality contributes to a sense of personal vulnerability which is magnified for those who perceive themselves to be spiritually different from the majority or norm and can also be a source of marginalisation in the workplace. There is also the issue of the exercise of power and whether organisations might attempt to apply spirituality as a leadership tool without the necessary personal commitment.

To sum up, workplace spirituality has been defined as the framework of organisational values that leads to a sense of the transcendence and interconnectedness of all life, so that workers experience personal fulfilment on the job (Giacalone \& Jurkiewicz 2003:99). This sense of transcendence, having a calling through one's work (vocation) and the need for membership in the corporate culture, community and social connections provides the foundation for a theory of workplace spirituality. Workplace spirituality is therefore framed within a holistic or system context of interwoven cultural, organisational and personal values. It must demonstrate its value by influencing performance, productivity and other relevant effectiveness and performance criteria. Evidence exists that suggests a link between workplace spirituality and 
enhanced individual creativity (Freshman 1999), increased honesty and trust within the organisation (Fry \& Slocum 2008; Giacalone \& Jurkiewicz 2003), an enhanced sense of personal fulfilment of employees (Burack 1999:281) and an increased commitment to organisational goals (McKee et al. 2011).

\section{Spirituality or religion in the workplace?}

Scholarly literature has tied spirituality to a religious context whereas others have not. Ali and Gibbs (1998) relate the Ten Commandments of the three major religions (Judaism, Christianity and Islam) to the work ethic and practice of believers. They argue that in a global marketplace and economy, with diversity as the norm rather than the exception, leaders and managers can benefit from understanding the basic embedded religious drives that members of these three religious may bring to their work environment. Elmes and Smith (2001) contend that workplace empowerment has a strong spiritual underpinning, with roots in Puritan and Christian ideals, emphasising hard work, right living and doing for others, which leads to individual and corporate prosperity. Pratt (2000), in his ethnographic research, found that deeply infusing religious values in an organisation putting God before one's business - can help members 'make sense' of unexpected religious and/or spiritual components.

In the Christian tradition spirituality is not just seen as human wellbeing, wholeness or meaning. It is a deeply lived experience of the person and nature of God in every aspect of life as a primary orientation. The concepts of vocation and shalom are amongst the most cherished of all doctrinal beliefs for adherents of the Christian faith. Both concepts have deep and broad implications for adherents as they pursue their daily professional lives. For Christians, human beings are created in the image of the Creator God. Thus exercising creativity in the world and extending the purpose of the Creator is a primary responsibility. Emphasising a particular Christian focus in the workplace would involve all employees subscribing to the Christian faith, which may or may not be possible. Some Christian organisations view their business as based upon 'management by the Word of God' - its structure is hierarchical and religious service is an important goal, along with profit. Organisations such as the Christian Business Network in South Africa are examples of Christian businesses that strive to support other Christian businesses and operate with standards of integrity that are in line with their faith commitment and seek to deliver customer service based on Christian values (see http:// www.christianbusinesses.co.za). It is hoped that this practice is befitting a Christian-based business and a witness to the Christian faith.

However, an overt religious agenda in business can be viewed as intolerant, exclusive and discriminatory to stakeholders. It often has the negative connotations of being parental, authoritarian and requiring unconscious obedience (King 2007). Adherence to a religious workplace orientation can lead to the belief that a particular company, faith or even race is somehow 'better' or worthier than another. The spirituality associated with such dogmatic proselytizing can take on the form of self-righteousness, and be used as a political tool against others (Nadesan 1999). It is important that workplace spirituality be separated from denomination polemics and the faith blanket in which it is frequently cloaked (Sass 2000:198) as viewing workplace spirituality through the lens of religious traditions is divisive. It excludes those who do not share in the denominational tradition and in some cases may conflict with the social, legal and ethical foundations of business and public administration (Schley 2008). What is preferred instead is not to promote a single religious (or Christian) framework but rather to create a structure and culture in which leaders and followers can respectfully negotiate religious and spiritual diversity (Hicks 2002). Being able to value human cooperation and teamwork, open dialogue and sharing of ideas will contribute to the practice of good workplace spirituality, and is equally a witness to the Christian faith.

Giving preferential treatment to one group over another, or accommodating one whilst imposing upon another, is not aligned with either the study or the application of workplace spirituality. Workplace spirituality therefore has to be inclusive of religious theory and practice. Several articles contend that spirituality should be seen as separate from any religious context (Giacalone \& Jurkiewicz 2003; Mitroff \& Denton 1999). Smith (1992) notes that all religions espouse the virtues of humility, charity and vision and there is much common ground between all world religions for these principles to be applied to workplace spirituality. Ashmos and Duchon (2000) argue that spirituality is neither about religion nor about getting people to accept a specific belief system. Rather it is about employees who understand themselves as spiritual beings at work whose souls need nourishment, a sense of purpose and meaning and a sense of connectedness to one another and to their workplace community. Whilst the Giacalone and Jurkiewicz (2003) definition includes transcendence and connection, it does not explicitly acknowledge religion as an integral aspect of workplace spirituality.

Concern for the separation of work and spiritual domains is further compounded by a parallel concern for the accommodation of employees' spirituality needs at work, such as the accommodation of religious dress or the need for flexible work schedules. Whilst the potential for abuse is clear, particularly in the form of religious harassment (King 2007:105), the need to accommodate spiritual issues is nonetheless important in maximising both productivity and satisfaction. At the same time, attention should be focused on developing frameworks for negotiating the everyday expressions of spirituality and religion and other potentially conflict-producing features of employee identity and diversity in the workplace (Hicks 2002:394).

It must be noted that whilst there is a distinction between religion and workplace spirituality, a leader's belief system accompanies his or her spirituality. Theory development 
should recognise that any form of spirituality also includes practices and beliefs (i.e. a religion) and that the accompanying beliefs are an important, if not more important element of the way in which someone's spirituality is manifest in his or leadership. Some studies (Fry 2003; Yukl 2002) describe leader belief systems in terms of values and/or attitudes and/or behaviour. Fry (2003) argues that leaders' values create their attitude, which drives their behaviours. One can imagine that there are numerous other beliefs in the religious or spiritual realms that individuals could hold that might influence their leader action and behaviours, for example, what they believe about corporate social responsibility or about a balanced work and family life. Research concludes that organisations must honour the whole person and the spiritual energy that is at the core of everything (Barrett 2003).

In South Africa, the dichotomy of work and religion is not a subject that has been vigorously debated, especially during the apartheid regime that claimed to uphold Christian values. Generally this dichotomy pervaded the work environment - the belief perhaps that if religion per se was allowed, it may promote a multitude of religious perspectives - thus threatening the neutrality of the workplace (Penceliah 2009:208). More robust discussion on religion and spirituality in the workplace is needed. Religion is valuable in that it also provides a conceptual framework for governance which may promote a leadership praxis linking the theory, practices and ethics of leadership (Duignan \& Bhindi 1997). The generally optimistic view of the value and benefits of spirituality in the workplace observed in the literature is consequently eroded by the paucity of empirical research on the subject in South Africa (Van Tonder \& Ramdass 2009). Research is needed to test the extent to which spiritual transformation includes the involvement of the Divine (Howard 2002:240) and whether the spiritual or religious beliefs of leaders have an impact on their actions (Smith \& Louw 2007:25-27).

\section{Spiritual leadership theory}

Over the last few decades significant advances have been made in integrating the theories of leadership and human development (Yukl 2002; Wilber 2000). Whilst empirical research on leadership remained narrowly focused on leadership behaviours, power dimensions, traits and skill and situational contexts, promising new areas of research have emerged that recognise leadership as the manifestation of a leader's spiritual core (Fairholm 1998), leadership as a collective phenomenon (Ashmos \& Duchon 2000) and leadership as concerned with the individual's thinking, enquiring, perceiving, valuing and acting in a community rather than an individual context (Eggerts 1998:223). These lines of research suggest the spiritual domain as an integral component of leadership and put forth spirituality as one variable of an integrated leadership development model (Sanders, Hopkins \& Geroy 2003; Wilber 2000). The premise of this integrated model is that as development occurs there is a transcending of worldviews and a shift to higher levels of internal locus of control (Sanders et al. 2003), and human growth is achieved through the interplay of individual, community and environment. At the higher stages of development, leaders are deepening their intuition and inner knowing through a shared consciousness with a higher power or transcendence.

Whilst scholars clearly identified spirituality as a central thesis of a new paradigm in organisational and leadership theory, the ontology of spirituality in the workplace closely resembles the literature on leadership in that there are dynamic dimensions or contexts for describing and measuring the phenomenon (Ashmos \& Duchon 2000; Cavenaugh 1999). Sometimes these dimensions confound one another; for example, spirituality is an attribute which remains relatively static over time versus the manifestation of spirituality, which can be dynamic and change depending on the situation. Some writers include ethics or team spirit within the boundaries although others do not, and some claim a nexus between spirituality and leadership practices whilst others treat workplace spirituality as an individual phenomenon (Benefiel 2003; Denton 2007; Northouse 2001). So as is evident, the field of study is marked by all of the typical characteristics of paradigm development including a lack of consensus about a definition of workplace spirituality and a lack of clarity about boundaries of the subject in context of leadership.

Most of the organisation theory that is offered in this area comes from the fields of Western religious theology and practice and leadership ethics and values (Blackaby \& Blackaby 2001; McNeal 2000; Northouse 2001). Perhaps the most comprehensive theoretical models towards developing a theory of spiritual leadership to date are Fairholm (1998) and Fry (2003). Fairholm (1998) was one of the first scholars to put the terms 'spiritual' and 'leadership' together to explain spirituality in context of workplace leadership, and since then others have attempted to validate his model in order to move the field toward a theory of leadership. Fairholm's (1998) model describes leadership as a personal reality one adopts to make sense of the dynamic interactive process of leadership. He argues for five virtual environments which include: leadership as management, leadership as excellent management, values leadership, cultural leadership and spiritual leadership. On the other hand, Fry (2003:693) defines spiritual leadership as 'the values, attitudes and behaviours that are necessary to intrinsically motivate self and others so that they have a sense of spiritual survival through calling and membership'. According to Fry (2003), spiritual leadership is seen as a causal theory based on an intrinsic motivation model that explores the concepts of positive human health and psychological well-being, character ethics, positive psychology and religion. It is causal, suggesting, for example, that hope/faith lead to vision/mission, which in turn leads to calling. Other authors (Cacioppe 2000; Tischler, Biberman \& McKeage 2002) have put forth spiritual leadership models that relate to constructs such as emotional intelligence, ethics, values and leadership models such as charismatic (Conger \& Kanungo 1994), stewardship (Block 1993), transformational (Bass \& Avolio 1994; Bass 2000) and 
servant leadership (Greenleaf 1977). These theories show that models are moving away from control towards influence, collaboration and partnership.

What should be required for a more comprehensive and integrated theory of leadership is an acknowledgement that leaders are complex beings who mature and develop over time in relationship to spiritual, emotional, cognitive, social and physical domains. Also, leaders have a need for desired transcendent-related work accomplishments (Sanders et al. 2003). In developing this integrated leadership theory, empirical results of the manifestations of leaders' spiritual beliefs, activities and practices should provide promising new ways to understand how leaders transcend and progress through the stages of human development.

\section{Spiritual leadership and organisational transformation}

Research suggests that when considering how to bring spirituality into the workplace, organisational culture needs to be transformed collectively (Denton 2007). This is done by transforming leadership where spiritual practices and values are incorporated into the culture of the organisation.

Spiritual leadership as a model for organisational development and transformation can guide the evolution of positive organisations in which human well-being and organisational level performance can not only co-exist but also be optimised (Dehler \& Welsh 1994; Neck \& Milliman 1994). Garcia-Zamor (2003:360) proposes that organisations need to establish themselves as worthy organisations, that is, organisations with a higher sense of business purpose. Howard (2002:240) suggests that organisations are exhibiting transformation characteristics when they attempt to use processes that engage people in communication through attempts at dialogue and meta-dialogue, that institute realtime strategy change, that use open space technology and lastly that encourages a culture of appreciative enquiry. These strategies show a commitment toward content (addressing spirituality explicitly) and process (working in ways that release the highest level of human potential). These changes can create a new organisational culture in which employees feel happier and perform better. This results in a culture of sharing and caring which will eventually reach all of the organisation's stakeholders and lead to good organisational performance. Since spiritual leadership taps into the leader's and the follower's fundamental need for spiritual survival and well-being through calling and membership, it has the potential to create vision and value congruence across individual, teams and organisational levels (Fry 2003; Lund Dean \& Safranski 2008). It ultimately fosters high levels of organisational commitment and productivity. However, to truly transform an organisation, leaders must be committed to a long-term spiritual vision and have the ability to stick with it over time.

According to Kolodinsky, Giacalone and Jurkiewicz (2008:265-266) the implementation of spirituality in the workplace can be viewed from an organisation-centred perspective, an individual-centered perspective or as interactive workplace spirituality:

- The organisation-based approach suggests that spirituality should be implemented to the organisation as a whole since conflicting preferences and interests between different individuals would impede the process. Organisations are classified into groups based on their principle of spirituality as religion-based, evolutionary, recovering, socially responsible and values-based (Mitroff \& Denton 1999:8-9).

- In the individual-centred perspective the organisation would not have a strict spiritual orientation but rather tries to accommodate and encourage spiritual requests from employees. Cash and Gray (2000), who provide a framework for dealing with spiritually related work accommodation, cite studies demonstrating that organisations are actively making reasonable accommodations for employee spirituality (recognising social and personal growth needs and accepting diverse beliefs and self-expression). Accommodations of any sort should reinforce the organisational mission of an innovative, progressive and productive culture.

- The third perspective, interactive workplace spirituality, entails the interaction of the individual employee's personal spiritual values with the spiritual values of the organisation.

The Mitroff and Denton (1999) study suggests that since there are many conflicting preferences and interests between individuals, it is not possible to allow individual spirituality; rather, the organisation should be changed as a whole. Mitroff and Denton (1999:9-13) view a best-practice model as one that begins with a values-based organisation and then incorporates aspects of the other spirituality models. For example, the commitment to spirituality is borrowed from the socially responsible organisation that aims to harness the power of business to resolve social problems and allow for morality and accountability in their dealings.

\section{Value-based leadership}

Value-based leadership is predicated on shared, strongly internalised values that are advocated and acted on by the leader (Bass \& Avolio 1994; House 1996; House \& Shamir 1993). Value-based leaders articulate a vision of a better future to energise extraordinary follower motivation, commitment, and performance by appealing to employees' values, enhancing their self efficacy and making their selfworth contingent upon their contribution to the leaders' mission and the collective vision (House \& Shamir 1993).

From an ethics and values perspective, leaders have an impact on establishing and reinforcing personal, team and organisational values (Northouse 2001). In an attempt to resolve the tension between workers' own personal and professional values, leaders promote change within their broader social settings. For example, an area in which such personal values are becoming increasingly prominent in 
the workplace is environmental protection. Many people hold a personal set of moral beliefs about the proper role of the organisation regarding the natural environment. These beliefs are held at the level of the individual and are formed through personal reflection, professional development, and association with other environmentally oriented individuals or cultural groups. With today's changing context of global environmental change, many religions are changing their views on the morality of behaviour towards the environment. The values underlying these beliefs inform an individualised sense of right and wrong that may be at odds with the dominant values in the workplace. With changes in such values come changes in conceptions of right and wrong in workplace behaviour that influence the environment, as well as the role of the manager in setting these conceptions. Many managers now see that role as spiritually motivated (Denton 2007:23). Further, this issue presents the tactics by which these spiritually motivated leaders act as organisational entrepreneurs, expressing their identities by fomenting change within their organisations. In so doing, they act as radicals or subversives, altering the dominant logics, metrics and values of the organisations through localised and discrete efforts at change. In this way, organisations and leaders work together to create the most committed of possible workforces by actively seeking to align professional and personal values.

Organisations are finding that a congruent fit between an individual's values and those of the organisation's culture is tied to organisational success. Value congruence models in psychology and organisational behaviour have looked at the fit between personal and organisational values (Chatman 1989). Barrett $(1998,2003)$ suggests that each level of Maslow's (1954) hierarchy of needs can be thought of as a level of consciousness, and that self-actualisation (the highest state) can be expanded to include four distinct stages in the development of spiritual awareness - transformation, cohesion, inclusion and unity. Barrett's model (2003) assumes that leaders who are able to operate from the full spectrum of consciousness and have a high degree of value alignment with their employees would outperform the market in customer satisfaction and shareholder value. Giacalone and Jurkiewicz (2003) posit that the greater the value congruence across levels, the more individuals will experience transcendence through their work and to the extent the organisation's culture reflects the global shift to post-materialistic altruistic values that tend to be more idealistic and spiritual, the more the individual will have a sense of connection, joy and completeness. When a greater fit exists between personal characteristics and organisational values, a variety of potentially desirable behaviours and attitudes ensues, including longer tenure, better performance and greater satisfaction (Ashforth \& Pratt 2003; Chatman 1991). This phenomenon is not lost in today's management world. Companies are finding that employees who act on their personal sense of workplace spirituality are more creative, self-directed, committed and desirable employees and are therefore highly sought after (DeFoore \& Renesch 1995; Hoffman n.d.).
Organisational transformation also begins with the willingness of a leader to examine their own values and behaviours. A key is to understand the shadow side of leadership: power, greed, the lure of wealth and the temptation to self-delusion, over-control and vanity. The importance of 'being' and personal integration should be prioritised over 'doing' if a leader is to avoid cynicism and burnout in the intensity of the leadership role. Four essential leader characteristics that followers admire and that give the leader credibility in motivating people to perform include being honest, forward-looking and inspiring in pursuit of a shared vision, and competence (Kouzes \& Pozner 1993). When people perceive their leaders to have high credibility, they are significantly more likely to be organisationally committed and productive.

It seems clear from both the religious and the values-based leadership approaches that leaders must get in touch with their core values and communicate them to followers through their vision and personal actions. Supporting autonomy and decision-making responsibility through self-managed, empowered teams and trusting people and letting them be who they are to use and develop their gifts are also essential. Spiritual leaders lead people through discourse and dialogue and believe that people, when they are involved and properly informed, can make intelligent decisions and can assume responsibility for decisions that affect their lives. It involves leading and managing by using values that drive fear and abuse out of the workplace and engage the hearts and minds of people (Kolodinsky et al. 2008). Hence a key contribution of spirituality to leadership is that leaders must seek to liberate others' responsibility for choices and so encourage personal growth.

\section{Conclusion}

A growing number of organisations are moving towards work arrangements that can be described as spiritual. The literature is filled with the promise of what the awareness of spirituality can do in an organisational context. However, lest the subject becomes a fad, researchers must use the utmost care in defining this concept and show how it is different from other concepts that can be used without the controversy of spirituality associated with them. For example, a South African study in the manufacturing industry found that sufficient consensus is emerging to convince institutional managers of the potential significance of workplace spirituality; however, the pragmatics of implementation are everything but uncomplicated (Van Tonder \& Ramdass 2009:239). Researchers should also ask whether the foundations of values-based leadership and other concepts of inspired leadership provide a comprehensive treatment without adding new labels or a new theory of leadership to the mix. Denton (2007:27) argues that measurement, whilst desirable, should not be the sole focus of attention. Even with an absence of measurement, he proposes that the spiritual movement is probably the most significant trend in management since the human-potential movement in the 50s. It appears to be a grassroots movement, as more and more 
people entertain the notion that work can be meaningful and fulfilling. This trend will endure, simply because it speaks to the deeper needs of the human heart and provides a promising remedy to declining job satisfaction.

In the developing context of the South African workplace that may not have reached the post-materialistic altruistic values of the global community, organisations mostly motivate workers through fear and extrinsic rewards. Hence, to keep the intrinsic motivation of spiritual survival alive is a challenge. However, especially because of contextual realities, spiritual leadership may not be sufficient in this highly unpredictable work world; but it does have certain potential for the transformation and success of organisations motivated by the serious re-evaluation of spiritual and moral values in our society. The workplace can no longer survive under the command and control leadership that was inspired by a mechanistic worldview, or be overwhelmed by the challenge. As Wheatley (1999) suggests:

no-one can hope to lead an organisation by standing outside or ignoring the web of relationships through which all work is accomplished. Leaders are being called to step forward as helpmates. (p. 39)

\section{Acknowledgements Competing interests}

The author declares that she has no financial or personal relationships which may have inappropriately influenced her in writing this article.

\section{References}

Ali A. \& Gibbs, M., 1998, 'Foundation of business ethics in contemporary religious thought: The ten commandments perspective', International Journal of Social Economics 25(10), 1152-1564. http://dx.doi.org/10.1108/03068299810214089

Arnold, K.A., Barling, J., Kelloway, E.K. \& McKee, M.C., 2007, 'Transformational leadership and psychological well-being: The mediating role of meaningfu work', Journal of Occupational Health Psychology 12(3), 193-203. http://dx.doi org/10.1037/1076-8998.12.3.193

Ashmos, D.P. \& Duchon, D., 2000, 'Spirituality at work: A conceptualization and measure', Journal of Management Inquiry 9(2), 134-145. http://dx.doi. org/10.1177/105649260092008

Ashforth, B.E. \& Pratt, M.G., 2003, 'Institutionalized spirituality: An oxymoron?', in R.A. Giaclone \& C.L. Jurkiewicz (eds.), Handbook of workplace spirituality and organizational performance, pp. 93-107, M.E. Sharpe, Armonk.

Barrett, R., 1998, Liberating the corporate soul, Butterworth-Heinemann, Boston.

Barrett, R., 2003, 'Culture and consciousness: Measuring spirituality in the workplace by mapping values', in R.A. Giaclone and C.L. Jurkiewicz (eds.), Handbook of
workplace spirituality and organizational performance, pp. 345-366, M.E. Sharpe, workplace
Armonk.

Bass, B.M. \& Avolio, B.J., 1994, Improving organizational effectiveness through transformational leadership, Sage, Thousand Oaks.

Bass, B.M., 2000, 'The future of leadership in learning organizations', Journal of Leadership Studies 3, 18-41. http://dx.doi.org/10.1177/107179190000700302

Benefiel, M., 2003, 'Irreconcilable foes? The discourse of spirituality and the discourse of organizational science', Organization 10(2), 383-391. http://dx.doi. org/10.1177/1350508403010002012

Blackaby, H. \& Blackaby, R., 2001, Spiritual leadership, Broadman \& Holman, Nashville. PMid:11358694

Block, P., 1993, Stewardship: Choosing service over self-interest, Berrett-Koehler, San Francisco.

Burack, E.H., 1999, 'Spirituality in the workplace', Journal of Organizational Change Management 12(4), 280-291

Cacioppe, R., 2000, 'Creating Spirit at work: Re-visioning organization development and leadership - Part 1', The Leadership and Organization Development Journal 2(1), 48-54. http://dx.doi.org/10.1108/01437730010310730

Cash, K.C, \& Gray, G., 2000, 'A framework of accommodating religion and spirituality in the workplace', Academy of Management Executive 14(3), 124-134.

Cavenaugh, G.F., 1999, 'Spirituality for managers: Context and critique', Journal of Organizational Change Management 12, 186-199. http://dx.doi. of Organizational Change Mand
org/10.1108/09534819910273793
Chatman, J.A., 1989, 'Improving interactional organizational research: A model of person-organization fit', Academy of Management Review 14, 333-349. http:// person-organization fit', Academy of Mand
dx.doi.org/10.5465/AMR.1989.4279063

Chatman, J., 1991, 'Matching people and organizations: Selection and socialization in public accounting firms', Administrative Science Quarterly 36, 459-484. http:// dx.doi.org/10.2307/2393204

Christian Business Network in South Africa n.d., Home page, viewed 18 December 2013, from http://www.christianbusinesses.co.za

Conger, J.A. \& Kanungo, R.N., 1994, 'Charismatic leadership in organizations: Perceived behavioural attributes and their measurement', Journal of Organizational Behavior 15, 439-452. http://dx.doi.org/10.1002/job.4030150508

Covey, S., 1995, First things first, Simon \& Schuster, New York. PMCid:PMC1236419

DeFoore, B. \& Renesch, J., 1995, Rediscovering the soul of business: A renaissance of values, New Leader Press, San Francisco.

Dehler, G.E. \& Welsh, M.A., 1994, 'Spirituality and organizational transformation: Implications for the new management paradigm', Journal of Managerial Psychology 9(6), 17-26. http://dx.doi.org/10.1108/02683949410070179

Delbecq, L.A., 1999, 'Christian spirituality and contemporary business leadership', Journal of Organizational Change Management 12(4), 345-349. http://dx.doi. org/10.1108/09534819910282180

Denton, M., 2007, 'A framework for spirituality into the workplace', World Journal of Management and Economics 1(2), 20-29.

Duignan, P. \& Bhindi, N., 1997, 'Authenticity in leadership: An emerging perspective', Journal of Educational Administration 35(3), 195-209. http://dx.doi. org/10.1108/09578239710170119

Eggerts, N., 1998, Contemplative leadership for entrepreneurial organizations: Paradigms, metaphors, and wicked problems, Quorum Books, Greenwood Paradigms, metaph
Publishing Group.

Elmes, M. \& Smith, C., 2001, 'Moved by the spirit: Contextualizing workplace empowerment in American spiritual ideals', The Journal of Applied Behavioral Science 37(1), 33-50. http://dx.doi.org/10.1177/0021886301371003

Fairholm, G.W., 1998, Perspectives on leadership: From the science of management to its spiritual heart, Praeger, Westport.

Freshman, B., 1999, 'An exploratory analysis of definitions and applications of spirituality in the workplace', Journal of Organisational Change Management 12(4), 318-327. http://dx.doi.org/10.1108/09534819910282153

Fry, W., 2003, 'Towards a theory of spiritual leadership', The Leadership Quarterly 14 693-727. http://dx.doi.org/10.1016/j.leaqua.2003.09.001

Fry, L.W. \& Slocum, J.W.J., 2008, 'Maximizing the triple bottom line through spiritual leadership', Organizational Dynamics 37(1), 86-96. http://dx.doi.org/10.1016/j. orgdyn.2007.11.004

Garcia-Zamor, J., 2003, 'Workplace spirituality and organizational performance', Public Administration Review 63(3), 355-363. http://dx.doi.org/10.1111/15406210.00295

Giacalone, R.A. \& Jurkiewicz, C.L., 2003, Handbook of workplace spirituality and organizational performance, M.E. Sharpe, New York.

Greenleaf, R.K., 1977, Servant Leadership: A journey into the nature of legitimate power and greatness, Paulist Press, New York. PMCid:PMC431078

Hicks, D.A., 2002, 'Spiritual and religious diversity in the workplace: Implications for leadership', The Leadership Quarterly 13, 379-396. http://dx.doi.org/10.1016/ S1048-9843(02)00124-8

Hoffman, A.J. n.d., 'Reconciling professional and personal value systems: The spiritually motivated manager as organizational entrepreneur', viewed n.d., from http://webuser.bus.umich.edu/ajhoff/pub_academic/2010\%20Workplace\%20 Spirituality.pdf

House, R.J., 1996, 'Path - goal theory of leadership: Lessons, legacy, and a reformulated theory', The Leadership Quarterly 7(3), 323-352. http://dx.doi. org/10.1016/S1048-9843(96)90024-7

House, R.J. \& Shamir, B., 1993, 'Toward the integration of transformational, charismatic, and visionary theories', in M. Chemmers \& R. Ayman (eds.), Leadership theory and research: Perspectives and directions, pp. 81-108, Academic Press, Orlando.

Howard, S., 2002, 'A spiritual perspective on learning in the workplace', Journal of Managerial Psychology 17(3), 230-242. http://dx.doi. org/10.1108/02683940210423132

King, S.M., 2007, 'Religion, spirituality, and the workplace: Challenges for public administration', Public Administration Review 67, 103-114. http://dx.doi. org/10.1111/j.1540-6210.2006.00700.x

Kinjerski, V. \& Skrypnek, B., 2004, 'Defining spirit at work: Common ground', Journal of Organizational Change Management 17(1), 26-42. http://dx.doi. org/10.1108/09534810410511288

Kolodinsky, R.W., Giacalone, R.A. \& Jurkiewicz, C.L., 2008, 'Workplace values and outcomes: Exploring personal, organizational and interactive workplace and outcomes: Exploring personal, organizational and interactive workplace
spirituality', Journal of Business Ethics 81, 465-480. http://dx.doi.org/10.1007/ spirituality', Journal

Kouzes, J.M. \& Pozner, B.Z., 1993, Credibility, Jossey-Bass, San Francisco. PMid:10127049

Lipps-Wiersma, M. \& Mills, C., 2002, 'Coming out of the closet: Negotiating spiritual expression in the workplace', Journal of Managerial Psychology 17(3), 183-202. http://dx.doi.org/10.1108/02683940210423097

Lund Dean, K. \& Safranski, S.R., 2008, 'No harm, no foul? Organizational intervention in workplace spirituality', International Journal of Public Administration 31, 359371. http://dx.doi.org/10.1080/01900690701590751

Maslow, A.H., 1954, Motivation and personality, Harper \& Row, New York.

McKee, M.C., Driscoll, C., Kelloway, K.E., \& Kelly, E., 2011, 'Exploring linkages among transformational leadership, workplace spirituality and well-being in health care workers', Journal of Management, Spirituality and Religion 8(3), 233-255. http:// dx.doi.org/10.1080/14766086.2011.599147 
McNeal, R., 2000, A work of the heart: understanding how God shapes spiritual leaders, Jossey-Bass, San Francisco.

Mitroff, I.I. \& Denton, E.A., 1999, A spiritual audit of corporate America: A hard look at spirituality, religion, and values in the workplace, Jossey-Bass, San Francisco.

Mohan, D.L., \& Uys, J.S., 2006, 'Towards living with meaning and purpose: Spiritual perspectives of people at work', SA Journal of Industrial Psychology 32(1), 53-59. http://dx.doi.org/10.4102/sajip.v32i1.228

Moxley, R.S., 2000, Leadership and spirit, Jossey-Bass, San Francisco. PMCid:PMC59022

Nadesan, M.H., 1999, 'The discourses of corporate spiritualism and evangelical capitalism', Management Communication Quarterly 13, 3-42. http://dx.doi. org/10.1177/0893318999131001

Neck, C.P, \& Milliman, J.F., 1994, 'Thought self-leadership: Finding spiritual fulfillment in organizational life', Journal of Managerial Psychology 9(6), 9-16. http://dx.doi. org/10.1108/02683949410070151

Northouse, P.G., 2001, Leadership: Theory and practice, Sage Publications, Thousand Oaks.

Penceliah, Y., 2009, 'The spiritual dimension of individuals in the context of the workplace', Alternation, Supplement, 199-217.

Pratt, M., 2000, 'Building an ideological fortress: The role of spirituality, encapsulation and sensemaking', Studies in Culture, Organizations \& Societies 6(1), 35-53. http://dx.doi.org/10.1080/10245280008523537

Ray, P. \& Anderson, S., 2000, The cultural creatives, Harmony Books, New York.

Rego, A. \& Pina e Cunha, M., 2008, 'Workplace spirituality and organizational commitment: An empirical study', Journal of Organizational Change Management 21(1), 53-75. http://dx.doi.org/10.1108/09534810810847039
Sanders, J.E., Hopkins, W.E. \& Geroy, G.D., 2003, 'From transactional to transcendental: Toward an integrated theory of leadership', Journal of Leadership \& Organizationa Studies 9(4), 21-29. http://dx.doi.org/10.1177/107179190300900402

Sass, J.S., 2000, 'Characterizing organizational spirituality: An organizational communication culture approach', Communications Studies 51, 195-207. http:// dx.doi.org/10.1080/10510970009388520

Schley, D.G., 2008, 'Legal aspects of spirituality in the workplace', International Journal of Public Administration 31, 342-358. http://dx.doi. org/10.1080/01900690701590744

Smith, H., 1992, The world's religions, Peter Smith, New York.

Smith, D.P.J. \& Louw, M., 2007, 'Conceptualization of the spiritual life dimension: A personal and professional leadership perspective', SA Journal of Human Resource Management 5(1), 19-27. http://dx.doi.org/10.4102/sajhrm.v5i1.104

Tischler, L., Biberman, J. \& McKeage, R., 2002, 'Linking emotional intelligence, spirituality and workplace performance', Journal of Managerial Psychology 17(3), 203-213. http://dx.doi.org/10.1108/02683940210423114

Van Tonder, C.L. \& Ramdass, P., 2009, 'A spirited workplace: Employee perspectives on the meaning of workplace spirituality', SA Journal of Human Resource Management 7(1), 230-241. http://dx.doi.org/10.4102/sajhrm.v7i1.207

Wheatley, M., 1999, Leadership and the new science: Learning of organizations from an orderly universe, Berett-Koehler, San Francisco.

Wilber, K., 2000, A theory of everything: Integral vision for business, politics, science, and spirituality, Shambhala, Boston. PMCid:PMC1885698

Yukl, GA., 2002, Leadership in organizations, Prentice Hall, Upper Saddle River. PMid:11820775 